\title{
COLLABORATIVE RELATIONSHIPS WITH CUSTOMERS: GENERATION AND PROTECTION OF INNOVATIONS
}

\author{
Jon Charterina (University of the Basque Country UPV/EHU) \\ Imanol Basterretxea (University of the Basque Country UPV/EHU) \\ Jon Landeta (University of the Basque Country UPV/EHU)
}

This is an electronic version of the accepted paper in Journal of Business \& Industrial Marketing

The definitive version is available at:

https://doi.org/10.1108/JBIM-02-2017-0052

Please, cite this article as:

Charterina, J., Basterretxea, I., \& Landeta, J. (2017). Collaborative relationships with customers: generation and protection of innovations. Journal of Business \& Industrial Marketing, 32(5). pp.733-741 
COLLABORATIVE RELATIONSHIPS WITH CUSTOMERS: GENERATION AND PROTECTION OF INNOVATIONS

Jon Charterina

Department of Business, Finance and Marketing, University of the Basque Country-UPV/EHU, Bilbao, Spain

Imanol Basterretxea

Department of Business, Finance and Marketing, University of the Basque Country-UPV/EHU, Bilbao, Spain

Jon Landeta

Institute of Business Applied Economics, University of the Basque Country-UPV/EHU, Bilbao, Spain

Abstract:

Purpose: To discover the key elements for generating and protecting innovations based on the customer-supplier relationship in industrial sectors

Methodology: Exploratory qualitative study performed using semi-structured interviews with CEOs and innovation managers of 22 industrial firms and institutions from the machine-tool (MT) industry

Findings: Key forms of knowledge must be shared by the two agents. Producers have to obtain in-depth knowledge about customers' needs and customers need knowledge on producer's absorptive capacity. Producers distinguish between three types of customer: reference customers, necessary for innovations with greatest scope, clientes amigos or test users, required to test innovations currently being developed, and traditional customers, associated with incremental innovations. The traditional means of protecting innovations is the detailed contract between customer and supplier; patents are used for innovations of greater technological scope, as a form of defense against third-party patents and as a signaling element of absorptive capacity.

Originality: The paper draws on the direct experience of executives from companies whose innovation is based on a close relationship with customers, in order to answer questions to which the literature has yet to provide definitive answers: What sort of information to be shared is relevant for the generation of innovations? Are all customers equal or are there profiles that contribute more effectively to the development of innovations? What attitude and mechanisms are most effective for protecting the knowledge and competitiveness generated through knowledge-sharing?

\section{Introduction}

Marketing and Management literature has stressed the importance of collaborative relationships with customers in the development of innovative products or services, as a source of innovation (Athaide \& Klink 2009, Bogers et al. 2010, Greer \& Lei 2012). In this regard, works on buyer-seller relationships, based on transactions cost analysis (TCA) have examined the circumstances under which collaboration or information exchange take place (Heide \& John 1990, Mohr \& Nevin 1990, Rindfleish \& Heide 1997). However, it is necessary to 
understand in greater detail under which circumstances value-generating knowledge from buying firms in a buyer-seller relationship is best gained. Particularly, in a context of bilaterally perceived risk of information spillover to third parties and lack of trust on the capabilities for developing the solutions demanded by the customer, the following questions need to be answered: What sort of information to be shared is relevant for the generation of innovations? What customer profiles contribute most effectively to the development of innovations? What attitude and mechanisms are most effective for protecting the knowledge and competitiveness generated by means of knowledge sharing? At this point, the framework of absorptive capacity (Cohen \& Levinthal 1990, Zahra \& George 2002) is useful, but not complete, for answering them. The literature on embedded ties between customer and supplier (Dyer \& Sing, 1998; Dyer and Nobeoka, 2000) and some empirical studies published (Charterina \& Landeta, 2010 and 2013; Charterina et al. 2015; Nordhoff et al. 2011, Valdés-Llaneza \& García-Canal, 2015) similarly fail to provide conclusive answers. This study therefore opts to use a qualitative methodology based on in-depth interviews with executives from companies that base improvement of their innovative capacity on building embedded ties with customers, as a means of inferring or exploring responses based on the experience of the actors involved.

The remainder of this study is organized as follows: the immediately following section offers insights on the concepts of absorptive capacity and the background literature on the opportunities and risks for a selling firm arising from the necessary embedded relations in development of a project. The third section describes the qualitative empirical research on cases, centering on the machine-tool industry and explains its main findings. Finally, the last section is a discussion of the results in the form of modified research proposals for further development.

\section{Conceptual background}

\subsection{Shared knowledge that contributes to improving innovative capacity.}

Knowledge has largely been recognized a critical resource for developing competitive advantages, especially in environments of intense global competition and rapid technological change (Teece 1998, Möller 2006). Firms cannot afford to develop knowledge alone in an entirely internal, self-sufficient way. Rather, in order to "understand the dynamics of the marketplace" and "know how to play what role in providing value", they need to establish inter-organizational relations as a means to gain short-term operational efficiency and longerterm new-knowledge creation (Malhotra, Gosain \& El Sawy 2005, p. 146). This is particularly true in the case of industrial small and medium-sized (SME) manufacturers, as a result of limitations such as capital scarcity, lack of management qualification, or limited access to technical information and know-how for innovation projects (Muller \& Zenker 2001, Narula 2004). Companies in general, and particularly SMEs, feel pressure to increase their ability to recognize ideas for innovation in their products from an in-depth knowledge of their customer firms' needs.

Profits can flow if relevant knowledge of customers' needs is obtained at an early stage and processed by the selling firm into solutions constituting innovations in the product or service sold (Alam 2002, Von Hippel, 1986). Cooperation with customers especially at early or late stages in development of a project becomes capital, as customer-related information can only be obtained from the customers themselves (Gruner \& Homburg, 2000).

Focusing attention to understand customers' needs is an example of "exposure to diverse and complementary external sources of knowledge" (Zahra \& George, 2002, p. 193), increasing the opportunity for the selling firm to develop potential absorptive capacities, where a firm's 
absorptive capacity is defined as its ability to recognize the value of new external information, assimilate it and apply it to commercial ends (Cohen and Levinthal, 1990).

Absorptive capacity is focused on understanding customers' needs, learning from them and quickly proposing convincing solutions during the initial steps in negotiation of a project. Therefore, it is probably one of the most valuable features a producer can have in gaining a contract. Accordingly, we posit the following research proposition:

RP1: Customers' needs are an important source of innovation and therefore a precise understanding of them is essential for improving the company's innovative capacity

There is a significant gap in understanding how knowledge is generated by an actor in a dyad or network and how it is identified, acquired and utilized by other participant actors (Tiwari, 2015). Scholars have tended to view absorptive capacity in terms of exposure to knowledge content, without a comprehensive understanding of the processes and structures allowing for interfirm knowledge flows (Lane, Koka \& Pathak 2006). An exception to this relative vagueness as to the processes of knowledge absorption is the conceptual study by Zahra and George (2002), which differentiates between acquisition, assimilation, transformation and exploitation capabilities, and groups the first two into the potential absorptive capacities (PACAP) subset, and the last two into the realized absorptive capacities (RACAP) subset. This further concretion of the model of absorptive capacity has been extensively used in conceptual and empirical studies on bio-pharmaceutical SMEs (Xia 2013), automotive supplier firms (Leal \& Roldán, 2013), scientific university parks (McAdam et al 2010), academic spin-offs (Taheri \& van Geenhuizen, 2010), industrial firms (Camisón \& Forés, 2010) and financial firms (Jansen et al. 2003).

The process of ascertaining the selling or contract maker firm's capabilities has been studied in the trust literature under the term "competence trust" (Das \& Teng 1998; Lui \& Ngo, 2004; Patzelt \& Shepherd 2008; Jiang et al 2015; Valdés-Llaneza \& García-Canal, 2015; Connelly et al. 2015). Competence trust is linked to good reputation and rich resources of capital and labor on the contractor firm's side (Lui \& Ngo 2004), the belief that the partner firm possesses the necessary resources and capabilities to meet the agreements of the alliance contract (McAllister, 1995, as cited by Patzelt \& Shepherd, 2008), or the partner's capability to perform a job, its skills and its professional knowledge (Jiang et al. 2015). However, these works do not refer specifically to the contracting firm's absorptive capacity, and this firm's efforts to signal it. Specific study of this process as one that ascertains the selling firm's absorptive capacity (Bergen, Dutta \& Walker, 1992; Kirmany \& Rao, 2000) is rarer. Thus:

RP2: In the process of negotiating a project, the selling firm's absorptive capacity is ascertained by the buying firm, as a signal of the former's suitability as a supplier. The selling firm makes an effort to signal this absorptive capacity

\subsection{Customer profiles and innovation generation}

According to Hansen (1999), there is a balance of strengths and weaknesses in facilitating search for and transfer of useful knowledge within the units of an organization. In particular, depending on the complexity of the knowledge to be transferred across subunits, Hansen found that strong ties provide the highest relative net effect in terms of a lesser amount of completion time when knowledge is highly complex. In contrast, weak ties are beneficial because they are less costly to maintain than strong ones, providing access to information at 
lower search costs, and being highly adequate for a non-complex kind of knowledge. To the extent that incremental innovation is more intense in the interchange of complex and tacit knowledge, it is assumed that embedded or strong ties play an important role (Huang \& Chang 2008).

For the case of relations with customers, Arnold, Fang and Palmatier (2011) studied the tradeoffs between the orientations in customer acquisition and retention, and radical and incremental innovation performance. They found that a focus on customer acquisition "enhances the diversity of customer knowledge development and resource exploration, which relates positively to greater radical innovation performance". On the contrary, "increasing a focus on customer retention enhances incremental innovation performance and undermines radical innovation" (p. 245). Also, it is argued that incremental innovations evolve within a strong tie, as this involves exchanges of more complex and tacit knowledge (Huang \& Chang, 2008). Therefore, the customer base and the effort invested in gaining new customers as against keeping the current base appear to determine the selling firms' innovative performance.

As stated, interaction with industrial customers and clients turns out to be a major source of innovations, particularly in the case of small and medium-sized firms (SMEs), in industries such as robotics (Kumaresan \& Miyazaki, 1999), construction (Vensström, 2008), and also machinery and machine-tool production, an industry particularly characterized by having a high proportion of relatively small firms (González, 2000). Very particularly in the case of the production of highly-customized and technology-intensive equipment, most of the innovative capacity of these producing firms comes from accessing customers with greater market power. Most importantly, it is by entering projects with these reference customers that the firm will have the capacity to generate innovations, helping it gain a preferential position in new business sectors. Obtaining specific knowledge from this type of customer can only be accomplished from the development of strong ties during project negotiation and execution.

Thus, our research propositions are:

RP3: Access in the form of projects with reference customers involves capacity for generating innovations and for gaining a preferential position in new business sectors.

RP4: The innovation derived from the relationship with the producer's traditional customers tends to be incremental in character.

RP5. The existence of embedded ties between customer and suppliers is a necessary prerequisite for the transmission of relevant knowledge and for the subsequent generation of innovations

\subsection{Embedded relations and the risk of knowledge spillovers}

Many studies have stressed the bright side of buyer-supplier collaborative relationships or embedded ties in the enhancement of innovation (Dyer and Singh, 1998; Nooteboom, 1999; Dyer and Nobeoka, 2000; Kaufman et al. 2000; Rindfleisch and Moorman 2001; Andersson et al. 2002; Selnes and Sallis, 2003; Uzzi and Lancaster, 2003). According to Uzzi and Lancaster, agents "embed their commercial transactions in social attachments and shift the logic of opportunism to a logic of trustful cooperative behavior in a way that creates a new basis for knowledge transfer and learning across firm boundaries" (Uzzi and Lancaster, 2003, p. 384). These strong collaborative relations must, therefore, favor knowledge exchange and the development of innovations.

However, there is also a broad base of research acknowledging the perceived risk of opportunism from the use of the transmitted knowledge in multiple forms. Partners in a 
strategic alliance tend to be protective of their valuable knowledge if there is a risk of spillover to competitors. Thus, the technology-supplier's ability to transfer its knowledge to the recipient while avoiding these negative effects becomes critical (Rose et al 2009). In the case of international strategic alliances in an asymmetrical learning context where a large gap exists in technical competence, the technically more advanced firm may be exposed to knowledge leaks in the form of property right infringements by the knowledge receiver. For its part, the less advanced (usually local) partner faces the risk of not being able to fully ascertain the value of knowledge from its partner (Tsang 1999). Also, given that the capabilities between the firms in a relationship differ, asymmetries of learning from the other alter their relative bargaining power, and lead to a reapportionment of skills between them (Hamel 1991, p. 84).

During the project development process there is knowledge and information to be transmitted or generated within the dyad. Mechanisms to appropriate the results of this knowledge and to protect it from spillover effects can be classified as formal -i.e. contracts, design rights, patents, copyrights and trademarks- and informal - secrecy, lead time, confidentiality agreements and complexity (Hall \& Sena, 2014). Selection of the right appropriability mechanism will depend on external and internal factors (Teece, 1986). The former include the nature of the implied technology and the efficacy of legal mechanisms for its protection. The internal factors include the distance of the own design from the dominant design paradigm, and control over some complementary assets such as marketing capabilities, competitive manufacturing or after-sales support (Teece, 1986).

In a context of weak appropriability, the use of formal mechanisms, such as contracts with customers and patents, to provide protection from innovation spillovers becomes crucial. In this regard, from the perspective of minimizing the transaction costs (Willianson, 1985), it may be presumed that patents can replace contracts as a mechanism for safeguarding the innovation generated.

Thus, our research propositions are:

RP6: The higher the limitations of informal appropriability of innovations, the more intensive the use of patents and contracts with the customer regulating disclosure and appropriability of knowledge produced during the execution of a project.

RP7: The greater the use of patents to protect an innovation, the less intensive the use of contracts with the customer, regulating disclosure and appropriability of knowledge produced during the execution of a project.

\section{3.- Methodology}

In this study we have used a qualitative approach by means of a cross-case analysis (Miles \& Hubermans, 1994; Patton, 2002), as a way of understanding the phenomenon of generation and protection of innovations based on the customer-supplier relationship, and responding to the research questions asked, within a given context, from a basically exploratory, inductive and flexible approach.

To this end, we conducted an empirical study consisting of twenty-two semi-structured indepth face-to-face interviews. The first interview was held with the CEO of the Spanish Association of Machine-Tool Producers, in order to get an overview of buyer-supplier relationships in the industry and their effect on innovation. This interview was also used to test the validity and relevance of the questions to be asked in following interviews and to gain firsthand information on some of the most innovative firms in the industry and the names of two key informants per firm. Armed with this information we conducted the interviews summarized in table 1. 
The interviews were recorded and transcribed, and subsequently analyzed by the three researchers, grouping and coding the transcriptions by themes and nodes of analysis.

The machine tool industry is particularly useful for an in-depth understanding of the dynamic of the processes of knowledge-sharing between industrial agents in a supplier-customer relationship. A basic characteristic of the industry studied, machine-tool making, is that currently all MT firms located in the Spanish and the European field are producers of highlycustomized equipment, selling on demand, and adapting their production to a great extent to the specifications demanded by the customer in each operation, in the form of a project:

"Our product is always a new machine, created 'ex professo'. So when you say: 'what value do we bring?'... well, to start with, something that is ad hoc...tailored for someone" [Ref. 21].

"Fortunately, our product is a relatively particularized product. It does not have large series. By the time it's in mass production, we'll be dead" [Ref. 5].

"Every project is an innovation project, as we do not offer machinery in series" [Ref. 8].

"Where there is product volume and it's not complicated, there you find the emergent market producers. So we have to go to tailored and technology-intensive products" [Ref.

11]

A second characteristic of this industry taken as an example of analysis is its high degree of concentration around market niches. In general, the Spanish MT industry, taken as an example, is divided into two sub-industries: metal cutting and metal forming. Specialization results from the intersection of three basic features: (1) the type of machine to be produced, (2) its size and other tailored features, and (3) the customer's profile. Producers generally focus on two or even one market niche. In this context, despite their eminently international nature, market niches tend to be relatively small:

In fact, in [very large] hydraulic presses, the latest data I have is that the market is between 500 million and 1 billion euros, which is a ridiculous figure...and there are probably about ten competitors worldwide [Ref. 21].

Also, this high degree of specialization sometimes even leads them to reject bids:

They need this. Can we make it? So, we have a bid acceptance committee..., customer bids are tracked...this one wants this head...or... wants a machine of this size, then that is accepted or rejected [Ref. 10].

Finally, in most cases, relationships are long-lasting in nature, enduring more than ten years. Satisfied customers tend to repeat. Therefore, indicators that are regarded valid for other industries, such as the ratio of new to total customers, are misleading in this industry.

\section{Main results}

The most evident result from all the analyzed cases is that direct contact with their customers' needs is always a very important source of information, if not the most important, which is in full agreement with RP1. Literally all of the interviewed companies emphasized this aspect: 
Table 1. Summary data of interviewed managers and firms.

\begin{tabular}{|c|c|c|c|c|c|c|}
\hline Ref No & Kind of firm & $\begin{array}{l}\text { Sales turnover } \\
31 / 12 / 2013 \\
\text { (in euros) } \\
\end{array}$ & Employees 2014 & US SIC & Type of machines & Interviewee \\
\hline 2 & SA & $36,455,889$ & 176 & 3545 & $\begin{array}{l}\text { Cutting tools, machine tool accessories and machinists' } \\
\text { precision measuring devices }\end{array}$ & Head of R\&D \\
\hline 3 & SA & $81,862,000$ & 156 & 3542 & Machine tools, metal forming types & Head of Innovation \\
\hline 5 & Co-Op & $33,790,000$ & 160 & 3523 & Farm machinery and equipment & CEO \\
\hline 6 & SL & $15,536,203$ & 54 & 3542 & Machine tools, metal forming types & Head of Innovation \\
\hline 7 & Technology center & & 8 corporations & $\begin{array}{l}\text { Research on metal forming } \\
\text { and assembly technology }\end{array}$ & & CEO \\
\hline 8 & Co-Op & $269,081,052$ & 636 & 3549 & Metalworking machinery, not elsewhere specified & CEO \\
\hline 9 & Technology center & & 9 corporations & Research on MT & Industrial production and manufacturing technologies & CEO \\
\hline 10 & SA & $46,064,000$ & 233 & 3542 & Machine tools, metal forming types & Sales Director \\
\hline 12 & SA & $17,703,367$ & 99 & 3569 & $\begin{array}{l}\text { General industrial machinery and equipment, not elsewhere } \\
\text { specified }\end{array}$ & $\begin{array}{c}\text { Head of Sales \& } \\
\text { Marketing } \\
\end{array}$ \\
\hline 13 & SA & $42,357,046$ & 117 & 3554 & Paper industries machinery & CEO \\
\hline 14 & SA & $35,498,740$ & 139 & 3545 & $\begin{array}{l}\text { Cutting tools, machine tool accessories and machinists' } \\
\text { precision-measuring devices }\end{array}$ & $\begin{array}{l}\text { Head of Sales \& } \\
\text { Marketing }\end{array}$ \\
\hline 15 & $\begin{array}{l}\text { MT producers' } \\
\text { association }\end{array}$ & & 170 corporations & & & CEO \\
\hline 16 & SL & & 24 & 3499 & Fabricated metal products, not elsewhere specified & Deputy General Director \\
\hline 17 & SAU & $10,890,437$ & 33 & 5084 & Industrial machinery and equipment wholesale dealing in & CEO \\
\hline 18 & SA & $8,888,159$ & 62 & 3562 & Ball and roller bearings & CEO \\
\hline 19 & SL & $4,661,811$ & 16 & 3499 & Fabricated metal products, not elsewhere specified & CEO \\
\hline 20 & Co-Op & $63,440,156$ & 214 & 3542 & Machine tools, metal forming types & CEO \\
\hline 21 & Co-Op & & 50 & 3561 & Pumps and pump equipment & CEO \\
\hline \multirow[t]{3}{*}{22} & SA & $2,300,656$ & 25 & 3562 & Ball and roller bearings & $\begin{array}{c}\text { Head of Innovation and } \\
\text { university professor of } \\
\text { Manufacturing and } \\
\text { Innovation }\end{array}$ \\
\hline & MEDIAN & $35,977,314.5$ & 128 & & & \\
\hline & MEAN & $51,447,450.6$ & 166.6 & & & \\
\hline
\end{tabular}

SA - sociedad anónima (publicly held limited liability company)

SL - sociedad limitada (private limited company)

SAU - sociedad anónima unipersonal (single-shareholder public limited company) 
As for innovations in the short run, the contribution made by the customer is vital ... [Ref. 8]

The customer comes, he has a need and is willing to pay for it. Of course, that is a source, yes indeed, for new product development. I would say it is the most important one [Ref. 9]

I would say that $75 \%$ of our innovation comes thanks to our customers. Another $15 \%$ comes from what we see among our competitors. That leaves 10\%, from which I would say 5\% comes from suppliers, and of the other 5\%, 3\% is made in-house, and $2 \%$ from our technological network [Ref. 11]

Secondly, according to our interpretation -drawn from an analysis of the literature cited above- and from the evidence as set out in the second proposition (RP2), during the process of negotiating a project, the vending company signals its capacity to absorb knowledge and the customer expressly examines this capacity. The selling of a new project to these reference customers often entails the need to develop new solutions for which there is not sufficient knowledge at the beginning of a project. Thus it is during the initial process of showing what their need involves, especially in the case of reference customers, that they assess the MT maker's absorptive capacity and trustworthiness:

The strongest point comes from the customer, when he confronts you with his need [Ref. 19]

The customer compares you with its needs, but for that to happen to you, you must have done something before with this customer to make it come to you, to present you with their idea, and for it to see you as being capable of achieving that development [Ref. 10]

The third research proposition focuses on the way customers discriminate depending on their knowledge base.

The results show the complexities and nuances of the evolving process of knowledge development. Generally, producers classify customers in two broad groups, reference and standard customers. Reference customers tend be technologically advanced firms with a strong prior knowledge of what they want and the characteristics that must be possessed by the solution they require. Standard customers, for their part, only tend to give details of their requirement.

Only the reference customers tend to be conducive to opportunities for gaining a preferential position in new business sectors:

There are customers whose engineering department is bigger than us, such as Audi [...] and they know very well what they want and how they want it [Ref. 11]

The most important changes and innovations have come with customers that I call 'reference customers', whom I don't know whether to call 'amigos' or not [Ref. 9]

Some producers have customers with whom they have a special relationship (i.e. cliente amigo or test users) allowing them to test improvements. These are not necessarily reference customers and are more present in incremental innovations or in innovation projects generated by the producer itself:

Here, I would distinguish two types of customers: collaborative customers (i.e. machine testers or 'clientes amigos') and reference customers. Machine testers are somewhat more present in incremental innovations and in product improvements incorporating a 
new technology, but basically in a product range of a more or less standardized kind [...] [Ref. 9]

To sum up, based on a qualitative analysis of the interviews conducted, it may be seen that the producers discriminate between their customers based on their degree of knowledge and according to their relationship with them. In this regard, they particularly appreciate those that give detailed indications of the type of technical solution they require, as opposed to other customers who merely state a generic need. It is precisely from the first group that the companies tend to learn most about new processes and gain access to new more profitable sectors, thus ratifying our RP3.

The relationship with the other, more traditional, customers, who basically require customized products, tends to lead to innovations of a smaller scope and of an incremental type, as proposed in RP4. Nonetheless, within this category there may be customers with strong trust and embedded ties with the producer who perform an important function in the generation of certain innovations, by acting as machine testers or innovation testers for the producer. These are what are termed "clientes amigos" or test users.

According to RP5, suppliers have a need to establish strong embedded ties during project negotiation and execution with reference customers as a necessary condition for generating innovations. With regard to this research proposition, it has been observed that the need for intense and continuous interaction is greater in projects with reference customers:

The customer participates to a great extent in the design phases; in other words, they don't just buy the machine and wash their hands of it until it's finished. They have to be convinced by the concept of the machine you make. Customers contribute things, because they know the process and the specific everyday needs. The fact that they contribute that gives you a lot of guidance on how you make those things. And that really does require quite a lot of relationship with the customer [Ref. 9]

I think co-engineering is great. [...], each part knows something. We both contribute something; [...] the customer knows one part, they know about the product, they know about the use, they know about productivity. And we know about the machine, so that collaboration works [...] [Ref. 11]

Our sixth research proposition poses that high limitations of informal appropriability of innovations lead to a more intensive use of patents and contracts regulating bilateral behavior. Those contracts would be aimed at minimizing the risk of knowledge disclosure during execution of a project, or to specify the property rights of the knowledge developed. The results show that, in general, information about a highly innovative improvement is usually carefully safeguarded by means of contracts:

A few days ago we were working on the fifth draft of our contract, but today we are on the seventeenth... Because both of us are innovating, and many things are changing, so the contracts also have to change [Ref. 11].

During discussion of a new project, before the customer has accepted the tender, the information disclosed to the customer refers more to the performance, efficiency and consumption and operating costs the equipment is capable of achieving. The producer tries to give away as little information as possible on technical details, such as construction drawings, electronic circuits, software, etc. or any detailed study of how their manufacturing process will be set up. However, once the final design has been signed, once there is a definite commitment set out in a contract to acquire the machine or installation, the obligation not to disclose secrets of intellectual property to third parties is also established, at the initiative of the party taking ownership of the innovation. 
Additionally, when the project involves a technical development that constitutes an innovation, much greater care is taken to specify who it belongs to and for how long. This ownership normally corresponds to the customer, at least temporarily, if this has been negotiated at the start of the project, or if the customer has met most of the research and development costs.

Some informants whose companies operate in very small business niches on a world scale say they have very little capacity to prevent opportunistic behavior on disclosure of information to third parties. These are sectors in which the customers sometimes imitate each other with the collaboration of a shared machine tool supplier.

On the hydraulic press market, we all know each other. Even the customers know each other and they discuss things amongst themselves. Things like best practice and benchmarking, which can be difficult in other industries, are not a problem here. Customers typically say, "Show me some similar machine you've sold to another customer". And what they want is not just to see the machine. They want to get into the [other customer's] plant to see how they have their cranes, how their run logistics, and so on; the machine is the least thing they want to see. So you go and spend a couple of hours there and they only spend three minutes looking at the machine... [Ref. 21].

The extent to which the relative lack of barriers to imitation in the industry is a source of concern for the executives interviewed varies depending on their perception of the dynamic capabilities of the firm itself (Teece et al. 1997). Executives of companies at the cutting edge in innovation and technology and with a positive perception of their own lead time as compared to the competition, are unafraid of imitators:

[...]It's not the same being copied, than being three years ahead [and using this time] to reach a higher level. It has much more to do with rhythm, being dynamic [Ref 11].

Are they copying you? Well, let them copy you.... and see how they do that [...] You are ahead of them [Ref 10].

In contrast, followers are more vulnerable to imitation:

Now Chinese firms are imitating us. They imitate our products and even our logo. The reality is that imitation is very [typical] of this industry: as it was in the past when we devoted ourselves to copying. Here the first machining center was made by buying one and taking it to pieces [...] We're not leaders in anything. We do the development; we're followers, so we get angry when they copy us and that's all [Ref. 6].

Most executives and companies interviewed questioned the use of patents. They commonly refer to them as "a waste of paper", and have a negative assessment of the cost-benefit relationship of patenting:

We used to patent our product, but as time went on, we saw that the practicality of those patents was limited and so we are moving more towards a situation of developing things without the need to patent them [Ref. 5].

Their view of the practical utility of protecting intellectual property by means of patents depends at least partly on the technical idea itself:

"It can be worthwhile patenting, depending on the type of product and engineering involved. When you make a disruptive innovation, which is not incremental [Ref 8]" 
Another key factor in deciding whether or not to patent is the possibility that the competition might gain access to alternative technical solutions to the idea protected by the patent. According to some informants, patenting sometimes has unintended negative consequences and makes imitation easier. For this reason, many informants prefer to keep their innovations under trade secret rather than patenting:

"There are some innovations where the best -or only-way of protecting them is industrial secrecy. Because the other way of doing it, which is to patent them... means going public and once I go public, my competitors are going to know about my innovation and it's going to be easier for them to understand our secret, or at least to know what our competitive advantages in our latest projects are based on." (Ref. 8)

Some of the reasons for patenting previously cited from Teece (1986) are evident here, particularly his distinction between environmental and internal factors - "the own technology and the type of knowledge embodied in the technology" (Teece 1986, as cited from Hall \& Sena 2014).

The largest and most innovative companies in our sample are the ones that patent most. As well as protecting radical innovations, these companies give another series of motives for patenting. One reason given in several interviews was the recognition that patents could potentially be an element of legal defense, especially for protecting them against any suits for infringement of intellectual property that might be brought by other competitors.

We patent for defense, as a defense logic. You take a long time to develop a good idea, whatever it may be, right from development stage and you finally achieve it... then five minutes later, the competition comes along and copies your idea. And you just say "Shit". [Ref. 4].

Patenting is a defensive tool, which blocks us at least for two or three years, so that in those two or three years we can corner the market. [Ref 13].

Another reason given for patenting in these more innovative companies is the value of patents as a marketing instrument for getting across the technological potential of the company and its absorption capacity.

Patenting is important; in particular, it's what customers value; a good way of measuring how innovative you are is to see how many patents you have [Ref 8].

In the sense given in RP6, it is plausible to presume that including nondisclosure clauses in a contract with the customer represents an additional means of protecting industrial secrets.

However, it has not been possible to gather explicit evidence that the existence of patents as a means of protecting the innovations generated has the effect of substituting for the use of contracts for the same purpose, as postulated in RP7. Ultimately, the two mechanisms appear to be complementary. The empirical evidence gathered in our sample is insufficient to elucidate or prove this proposition better.

\section{Conclusions and implications}


Several studies have shown the positive relationship that the transmission of relevant knowledge between customer and supplier has in improving their respective innovative capacities in complex and customized projects. Our study has highlighted two fundamental forms of knowledge for this purpose: in-depth knowledge of the customer's need, as the true origin of the launch of the innovation, and the customer's knowledge of the supplier's absorption capacity. Firms that want to highlight their innovative capacity in industries similar to that studied need to pay particular attention to both types of knowledge-sharing.

Secondly, the study examines in greater depth the customer profile with the greatest access to any knowledge that constitutes innovations. The most common industrial customers of the companies interviewed normally stated a need for a machine adapted to their needs. Incremental innovations tend to arise from the relationship with those customers. The second type of customers are the so-called "reference customers", firms that are looking for an innovative solution to a technical problem they face, involving a machine or set of machines, and who moreover possess knowledge that is very closely linked to the technical solution they require. These reference customers are leading companies in the automobile, aeronautical and other industries with a high technological and innovation component, belonging to large industrial groups, normally much larger than the suppliers analyzed, and which moreover are industry leaders. For this type of relation, prior embedded ties between customer and supplier are not strictly necessary, if the supplier is capable of signaling its absorptive capacity appropriately. They do, however, become necessary later on, during development of the project, in order to allow knowledge to flow in both directions. The firms consulted that have reference customers in their order portfolio have greater expectations of benefitting from radical innovations or of forming themselves into initiators and leaders of new products, in this case, machines and installations.

Finally, there is another type of customer, the so-called "clientes amigos" or test-users, who do have a strong trust-based relationship with the supplier. These customers are especially useful in developing innovations that arise from the producer's own innovating drive and which the producer needs to test with the collaboration of these amigos, before offering them as part of its product portfolio. Therefore, it appears that having a balanced portfolio of customers, with customers from the three categories is recommendable for sustained improvement of innovative capacity.

As a third chief conclusion, it has been seen that the companies analyzed show different attitudes and practices with regard to the risk of knowledge spillover to third parties. The basic mechanism for protecting innovation is the contract. In the industry analyzed in this study, it is essential for regulating agreements on sale of the machinery involved in the project and for regulating disclosure and appropriability of the knowledge produced. It is common practice for the contract to establish ownership of any technological developments occurring during the project, and to require that such industrial secrets be held confidential.

However, there are differences of opinion with regard to the general usefulness of patents as a mechanism for protecting intellectual property. The difficulty for a relatively small firm lies in meeting the cost of the patent and, especially, in ensuring that it is respected in a global market. Moreover, many of the companies interviewed stated a preference for protecting their innovations via trade secret rather than via patenting. They argue that patenting involves revealing the innovation and the source of competitive advantage to competitors and, thus, making imitation easier. Besides, they argue that most innovations in the industry are incremental and radical innovations capable of being patented are rare.

Nonetheless, the companies that show the greatest leadership position in their niche are the most inclined to recognize the value of patents and are, indeed, those that state they have a greater number of their own patents, resulting from their greater technological advance. They 
do this as an appropriability mechanism, but also as a defensive mechanism against possible third-party patents of solutions they have developed and as a signal of their own technological and absorptive capacity. This, combined with the recognition of their own knowledge absorption capacity and the awareness of a lead time factor in their favor, means that they are less afraid of suffering knowledge spillover effects than other companies analyzed with a more modest technological profile.

Consequently, companies must make a strong effort to use formal mechanisms of protection of their innovations: contracts, generally, and patents, provided that the scope of innovation justifies the investment in time and money.

Finally, it has not been possible to show in this industry that registering intellectual property by way of patents is a substitute for the use of contracts as a mechanism for protecting the knowledge produced.

The main limitations of this study are those inherent to the type of qualitative research performed: the results are explorative, obtained from a varied, but limited, sample of companies operating in a specific industry and geographical area. Any generalization of these results should therefore be treated with caution. Most of the companies interviewed were small in size and their most common form of innovation was incremental in character.

Future research might compare these conclusions against other geographical or sectoral environments, with larger samples of bigger companies, differentiating by types of innovation, by means of other qualitative studies of a different scope or quantitative studies that allow greater generalization of the results.

In addition, the situation highlighted here whereby producers of industrial equipment have to maximize their absorptive capacity (Cohen \& Levinthal 1990, Zahra \& George 2002) while at the same time successfully signaling their know-how (Bergen, Dutta \& Walker, 1992; Kirmani \& Rao 2000) has not yet been sufficiently studied. The forms of absorption of knowledge by companies and their transformation into innovations still requires more research to show how, when and why they are carried out.

Bibliography:

Alam, I. (2002). "An Exploratory Investigation of User Involvement in New Service Development". Journal of the Academy of Marketing Science, Vol. 30 No.3,pp.250-261

Andersson, U. Forsgren, M. and Holm, U. (2002). The strategic impact of external networks: Subsidiary performance and competence development in the multinational corporation, Strategic Management Journal, Vol. 23, Iss. 11, pp. 979-996. DOI: 10.1002/smj.267

Arnold, T.J., Fang, E. and Palmatier, R.W.(2011). The effects of customer acquisition and retention orientations on a firm's radical and incremental innovation performance, Journal of the Academy of Marketing Science, Vol. 34. Pp. 234-251. DOI 10.1007/s11747-010-02038

Athaide, G.A. \& Klink, R.R. (2009). Managing Seller-Buyer Relationships during New Product Development. Journal of Product Innovation Management, 26, pp. 566-577.

Bergen, M., Dutta, S., and Walker, Jr., O. C. (1992). Agency Relationships in Marketing: A Review of the Implications and Applications of Agency and Related Theories, Journal of Marketing, Vol.56, No.3, pp.1-24.

Bogers, M., Afuah,A. \& Bastian, B. (2010). Users as Innovators: A Review, Critique, and Future Research Directions. Journal of Management, 36(4), pp. 857-875

Camisón C. and Forés, B. (2010). Knowledge absorptive capacity: New insights for its conceptualization and measurement, Journal of Business Research, Vol. 63, pp. 707-715 
Charterina, J. and Landeta, J. (2010). The pool-effect of dyad based capabilities on seller firms' innovativeness, European Journal of Innovation Management, Vol. 13, No.2, pp. 172-196.

Charterina, J. and Landeta, J. (2013). Effects of Knowledge-sharing Routines and Dyad-based Investments on Company Innovation and Performance: An Empirical Study of Spanish Manufacturing Companies, International Journal of Management, Vol. 30, No.1, pp. 20-39.

Charterina, J. Basterretxea, I. and Landeta, J. (2015). Types of Embedded Ties in Buyer-Supplier Relationships and Their Combined Effects on Innovation Performance, Journal of Business and Industrial Marketing, Vol.3, no. 12, pp. 152-163.

Cohen, W. M. and Levinthal, D. A. (1990). Absorptive capacity: a new perspective on learning and innovation. Administrative Science Quarterly, Vol. 35, No.1, pp. 128-152.

Connelly, B.L., Ketchen, D.J., Crook, T.R. and Combs, J.G. (2015). Competence- and IntegrityBased Trust in Interorganizational Relationships: Which Matters More?. Journal of Management. Vol. XX No. X, Month XXXX 1-27, DOI: 10.1177/0149206315596813

Das, T. K., \& Teng, B. S. 1998. Between trust and control: Developing confidence in partner cooperation in alliances. Academy of Management Review, Vol. 23, No.3, pp. 491-512.

Dyer, J.H. and Nobeoka, K., 2000. Creating and managing a high-performance knowledgesharing network: the Toyota case. Strategic Management Journal, Vol. 21, No. 3, pp. 34567.

Dyer, J.H. and Singh, H. (1998). "The relational view: Cooperative strategy and sources of interorganizational competitive advantage". Academy of Management Review, Vol. 23, No. 4, pp. 660-679.

González, A.Mạ. (2000): Análisis de la competitividad de la industria española de máquinaherramienta en el marco de la Unión Europea. PhD Thesis, Universidad del País Vasco / Euskal Herriko Unibertsitatea.

Greer, C.R. and Lei, D. (2012). "Collaborative Innovation with Customers: A Review of the Literature and Suggestions for Future Research". International Journal of Management Reviews, Vol. 14, pp. 63-84.

Gruner, K.E. and Homburg, C. (2000). Does Customer Interaction Enhance New Product Success?. Journal of Business Research, Vol. 49, pp. 1-14

Hall, B.H. and Sena, V. (2014). Appropriability Mechanisms, Innovation and Productivity: Evicence From the UK, NBER Working Paper Series, Working Paper 20514. Retrieved from: http://www.nber.org/papers/w20514

Hamel, G. (1991). Competition for Competence and Inter-Partner Learning Alliances Within International Strategic Alliances, Strategic Management Journal, Vol. 12, Special Issue: Global Strategy (Summer), pp. 83-103. Retrieved from: http://www.jstor.org/stable/2486643

Hansen, M.T. 1999. The Search-Transfer Problem: The Role of Weak Ties in Sharing Knowledge across OrganizationS ubunits. Administrative Science Quarterly, Vol. 44, pp. 82-111

Heide, J.B., and George J. 1990. "Alliances in Industrial Purchasing: The Determinants of Joint Action in Buyer-supplier Relationships". Journal of Marketing Research, Vol .27, No. (1),. American Marketing Association, pp. 24-36. doi:10.2307/3172548.

Huang, H.C. and Chang, C.W, (2008),"Embedded ties and the acquisition of competitive advantage", Journal of Intellectual Capital, Vol. 9 Iss 1 pp. $105-121$.

http://dx.doi.org/10.1108/14691930810845830

Jansen, J.J.P., Van Den Bosch, F.A.J. and Volerda, H.W. (2003). Absorptive Capacity, Adaptation, and Performance. An Intra-Organizational Perspective. Proceedings of the OKLC Conference. Barcelona (April 13-14).

Jiang, X, Jiang, F. Cai, X. and Liu, H.(2015). How does trust affect alliance performance? The mediating role of resource sharing. Industrial Marketing Management, Vol. 45, pp. 138138.

Kaufman, A., Wood, C. H., \& Theyel, G. (2000). Collaboration and Technology Linkages: A Strategic Supplier Typology. Strategic Management Journal, Vol. 21, No.6, pp. 649-663. 
Kirmani, A. and Rao, A.R. (2000). No Pain, No Gain: A Critical Review of the Literature on Signalling Unobservable Product Quality. Journal of Marketing, Vol. 64(2), pp. 66-79.

Kumaresan, N. and Miyazaki, K. (1999). An integrated network approach to systems of innovation - The case of robotics in Japan. Research Policy, Vol. 28, No. 6, pp. 563-585.

Lane, P.J., Koka, B.R. and Pathak, S. (2006). The reification of absorptive capacity: A critical review and rejuvenation of the construct. Academy of Management Review, Vol. 31, Iss. 4, pp. 833-863

Leal-Rodríguez. A.L. and Roldán, J.L. (2013). The moderating role of relational learning in the PACAP-RACAP link. A study in the Spanish automotive components manufacturing sector. Revista Europea de Dirección y Economía de la Empresa, Vol. 22, pp. 218-224.

Lui, S.S. and Ngo, H.Y. (2004). The Role of Trust and Contractual Safeguards on Cooperation in Non-equity Alliances, Journal of Management, Vol. 30, No. 4, pp.471-485.

Malhotra, A. Gosain, S and El Sawy, O.A. (2005). "Absorptive Capacity Configurations in Supply Chains: Gearing for Partner-Enabled Market Knowledge Creation". MIS Quarterly, Vol. 19, No. 1, pp. 145-187.

McAdam, M., McAdam, R., Galbraith, B. and Miller, K. (2010). An exploratory study of Principal Investigator roles in UK university Proof-of-Concept processes: an Absorptive Capacity perspective. R\&D Management, Vol. 40, No. 5, pp.455-473.

McAllister, D. J. (1995). 'Affect- and cognition-based trust as foundations for interpersonal cooperation in organizations'. Academy of Management Journal, 38, 24-59.

Miles, M.B. and Huberman, A.M. (1994). Qualitiative Data Analysis. An Expanded sourcebook. $2^{\text {nd }}$ Edition. Thousand Oaks, CA: SAGE.

Mohr, J. and Nevin, J.R. (1990). Communication Strateges in Marketing Channels: A Theoretical Perspective. Journal of Marketing, Vol. 54, No. 4, pp. 36-51.

Möller, K. (2006). Role fo competences in creating customer value: A value-creation logic approach. Industrial Marketing Management. Vol. 35, No.8, pp. 913-924

Muller, E. and Zenker, A. (2001). Business services as actors of knowledge transformation and diffusion: some empirical findings on the role of KIBS in regional and national information systems. Fraunhofer Institute. Systems and Innovation Research. Working Papers Firms and Region No. R2/2001.

Narula, R. (2004). R\&D Collaboration By SMEs: New Opportunities and Limitations In The Face of Globalization, Technovation, Vol. 24, Issue 2, pp. 153-161.

Nordhoff, C.S., Kyriakopoulos, K., Moorman, C. Pauwels, P. and Dellaert, B.G.C. (2011). The Bright Side and Dark Side of Embedded Ties in Business-to-Business Innovation. Journal of Marketing, Vol. 75 (September), pp. 34-52

Noteboom, B. (1999). Innovatoin and inter-firm linkages: new implicatios for policy, research Policy, Vol. 28, No. 8. pp.793-805

Patton, M.Q. (2002). Qualitative Research \& Evaluation Methods, London: Sage

Patzelt, H. and Sheperd, D.A. (2008). The Decision to Persist with Underperforming Alliances: The Role of Trust and Control. Journal of Management Studies, Vol. 45, No. 7 pp. 1217-1243.

Rindfleish, A. and Heide, J.B. (1997). Transaction Cost Analysis: Past, Present and Future Applications, Journal of Marketing, Vol. 61, No. 4, pp. 30-54

Rindfleish, A. and Moorman, C. (2001). The Acquisition of Information in New Product Alliances: A Strength-of-Ties Perspective. Journal of Marketing, Vol. 65, No. 2, pp. 1-18

Rose, R.C.; Uli, R.; Kumar, N. and Wahab, S.A. (2009). A review on the Effects of Inter-Firm Technology Transfer Characteristics and Degree of Technology Transfer. European Journal of Social Sciences, 8(2), pp.297-309.

Selnes,F. and Sallis, J.(2003). Promoting Relationship Learning, Journal of Marketing, Vol. 67, Iss.3, pp.80-95.

Taheri, M. and van Geenhuizen, M. (2010). Spatial reach in learning of academic spin-offs - A focus on absorptive capacity. Proceedings of the HTSF Doctoral Workshop and Conference, May $25-28^{\text {th }}$, University of Twente, Enschede, The Netherlands. 
Teece, D.J. (1986). Profiting from technological innocation: Implications for integration, collaboration, licensing and public policy, Research Policy, Vol. 15, pp. 285-305.

Teece, D.J. (1998). Capturing Value from Knowledge Assets: The New Economy, Market for Know-How and Intangible Assets. California Management Review, Vol. 40, No.3, pp. 55-79.

Teece, D.J.; Pisano, G. and Shuen, A. (1997). Dynamic Capabilities and Strategic Management. Strategic Management Journal, Vol. 18 No. 7, pp. 509-533.

Tiwari, S.R. (2015). Knowledge Integration in Government-Industry Project Network. Knowledge and Process Management, 22(1), pp.11-21.

Tsang, E.W.K. (1999). A Preliminary Typology of Learning in International Strategic Alliances. Journal of World Business. 34(3), pp. 211-229.

Uzzi, B. (1996). The sources and consequences of embeddedness for the economic performance of organizations: the network effect. American Sociological Review, Vol. 61, No. 4, pp. 674-698.

Uzzi, B. (1997). Social structure and competition in inter-firm networks: The paradox of embeddedness. Administrative Science Quarterly, Vol. 42, pp. 35-67.

Uzzi, B. and Lancaster, R. (2003). Relational Embeddedness and Learning: The Case of Bank Loan Managers and Their Clients, Management Science, Vol. 49, No. 4, pp.383-399. Doi: // 0025-1909/03/4904/0383\$05.00

Valdés-Llaneza, A. and García-Canal, E. (2015). The devil you know? A review of the literature on the impact of prior ties on strategic alliances. Management Research: The Journal of the Iberoamerican Academy of Management, Vol. 13, Iss. 3, pp. 334 - 358

Vennström, A.(2008). The Construction Client as a Change Agent-Contextual Support and Obstacles. Ph.D. Thesis, Luleå University of Technology, Department of Civil, Mining and Environmental Engineering. Division of Architecture and Infraestructure Source

Villena, V., Revilla, E. and Choi, T. (2011). The dark side of buyer-supplier relationships: a social capital perspective. Journal of Operations Management, Vol. 29, pp. 561-576.

Von Hippel, E.(1986). Lead Users: A Source of Novel Product Concepts, Management Science, Vol 32, No.7, pp. 791-805

Williamson, O.E. (1987). The Economic Institutions of Capitalism, New York: The Free Press.

Xia, T. (2013). Absorptive capacity and opennesss of small biopharmaceutival firms- a European Union - United States comparison, R\&D Management, Vol. 43, No.4, pp.333-351.

Zahra, S.A. and George, G. (2002). Absorptive Capacity: A Review, Reconceptualization, and Extension. Academy of Management Review, Vol. 27, No. 2, pp. 185-203. 